\title{
PERFORMANCE OF HELICAL METERING MECHANISMS IN THE APPLICATION OF MICROGRANULAR FERTILIZER
}

\author{
Roger T. Spagnolo ${ }^{*}$, David P. da Rosa ${ }^{2}$, Marivan da S. Pinho ${ }^{1}$, \\ Cheiner S. Schiavon ${ }^{1}$, Diego K. Schmechel ${ }^{1}$
}

${ }^{1 *}$ Corresponding author. Universidade Federal de Pelotas (UFPel)/ Pelotas - RS, Brasil.

E-mail: roger.toscan@gmail.com | ORCID ID: https://orcid.org/0000-0002-0287-2561

\section{KEYWORDS}

agricultural

equipment, longitudinal inclination, precision agriculture.

\begin{abstract}
The use of microgranular fertilizers is currently increasing, with low application rates as an obstacle in the mechanization. This study aimed to verify the performance of helical metering mechanisms using microgranular fertilizer. Four different fertilizer-metering mechanisms were tested at two pre-established dose rates $\left(35\right.$ and $\left.50 \mathrm{~kg} \mathrm{ha}^{-1}\right)$ and seven longitudinal angles $\left(-15^{\circ},-10^{\circ},-5^{\circ}, 0^{\circ},+5^{\circ},+10^{\circ}\right.$, and $\left.+15^{\circ}\right)$. The experiment was carried out according to Brazilian standards. The results showed that the longitudinal inclination affects the actual fertilizer dose in all tested metering systems. Metering mechanisms with a helicoid with longitudinal and lateral overflow presented a similar dose, according to the variation of the longitudinal inclination. The metering mechanism with two helicoids showed the highest dose variation, while the metering mechanism with a helical thread and longitudinal overflow, filled between the shaft and the helicoid, had the best performance.
\end{abstract}

\section{INTRODUCTION}

Sowing is a practice that needs high precision, as it is one of the first stages within the production process of a given crop, being responsible for placing the seed and creating an environment for its development, and problems at this stage may not be reversed throughout the crop cycle (Ferreira et al., 2010).

In the Brazilian scenario, around $94.4 \%$ of seedcum-fertilizer drills are equipped with helical- or augertype fertilizer metering mechanisms (Francetto et al., 2015), found in different models and showing changes relative to the metering principles, i.e., gravity and overflow. Gravity models have one thread or two threads with an inverted rotation, and overflow models have longitudinal or lateral overflows.

These metering mechanisms have dose variations that can reach 70\% (Reynaldo \& Gamero, 2015; Garcia et al., 2017; Rosa et al., 2019). In addition to the constructive characteristics (Garcia et al., 2012; Galvão et al., 2018), working inclination and fertilizer moisture and particle size (Reynaldo \& Gamero, 2015; Spagnolo et al., 2018) are the main factors that influence this dose variation.
The supply of fertilizers with different formulations has been increasing in the market for granular fertilizers, various with microgranular characterization. However, there is a lack of information regarding their distribution by seed-cum-fertilizer drills. In this sense, this study aimed to verify the performance and carry out the modeling of four helical screw fertilizer-metering mechanisms of seed-cumfertilizer drills when dosing microgranular fertilizer at different longitudinal inclinations.

\section{MATERIAL AND METHODS}

The tests were carried out at the Engineering Center (CEng) unit of the Federal University of Pelotas on a test bench (Figure 1) powered by a $12 \mathrm{~V}$ motor, with the speed control of the metering drive shaft carried out with a power supply pulse-width modulation (PWM). The metering mechanisms were tested individually although the bench has more than one system.

The helicoid pitch was used in the tests for the metering mechanisms M1, M3, and M4 of $25.4 \mathrm{~mm} \mathrm{(1"),}$ while the metering mechanism M2 used an equivalent pitch thread of $15.9 \mathrm{~mm}\left(5 / 8^{\prime \prime}\right)$. The tested longitudinal inclinations were $-15^{\circ},-10^{\circ},-5^{\circ}, 0^{\circ},+5^{\circ},+10^{\circ}$, and $+15^{\circ}$.

\footnotetext{
${ }^{1}$ Universidade Federal de Pelotas (UFPel)/ Pelotas - RS, Brasil.

${ }^{2}$ Instituto Federal de Educação, Ciência e Tecnologia do Rio Grande do Sul - Campus Sertão (IFRS)/ Sertão - RS, Brasil.
} 


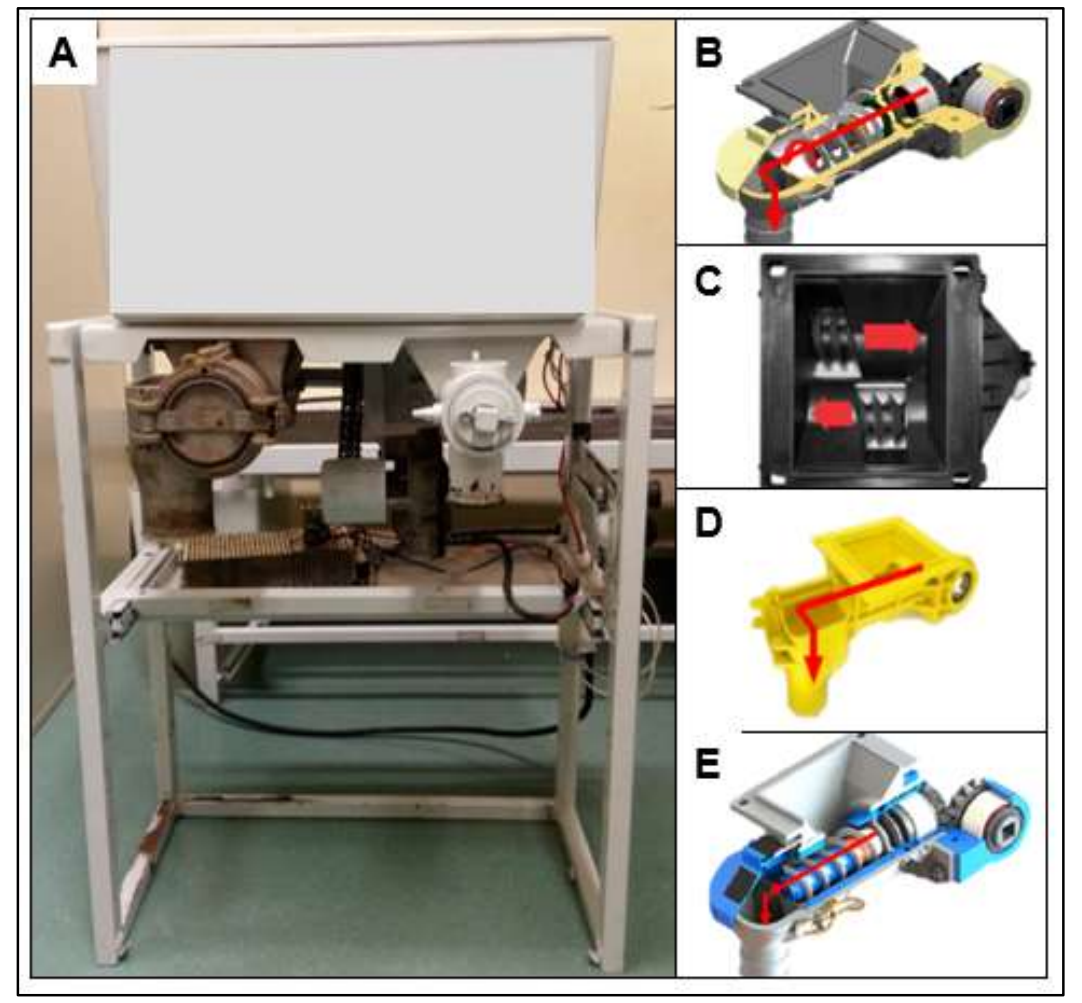

FIGURE 1. Test bench for fertilizer screw metering mechanisms (A) of the types helical by longitudinal overflow - M1 (B), helical by gravity with two helicoids - M2 (C), helical by lateral overflow - M3 (D), and helical by longitudinal overflow for microgranular fertilizers - M4 (E).

The pre-established dose was 35 and $50 \mathrm{~kg} \mathrm{ha}^{-1}$, which are considered low but recommended by the manufacturer for crops such as corn, soybean, wheat, and rice. The doses were measured using a modification in the rotation of the fertilizer-metering shaft to quantify the fertilizer mass dosed in 30 seconds with the bench at $0^{\circ}$ of inclination, considering a seed-cum-fertilizer drill in level, with a speed of $1.39 \mathrm{~m} \mathrm{~s}^{-1}$ and distance between rows of $0.45 \mathrm{~m}$.

The Rizobacter ${ }^{\circledR}$ Rizostar mixed mineral fertilizer with a formulation of 10-40-00, consisting of nitrogen, phosphorus, sulfur, and zinc, was used. The angle of repose was $32.4^{\circ}$, with a density of $1007 \mathrm{~kg} \mathrm{~m}^{-3}$ and a water content of $1.52 \%$ on a dry basis. The particle size analysis consisted of $0.15,53.08$, and $99.45 \%$ of material retained and accumulated in sieves of 2,1 , and $0.5 \mathrm{~mm}$ (ABNT, 2003).

Tests were carried out according to the ISO 5690/2 (1984) methodology. Each collection lasted 30 seconds, which was preceded by 15 seconds for the stabilization of the fertilizer mass flow, totaling 45 seconds each test. The collections were carried out in polypropylene trays $(200 \mathrm{x}$ $150 \times 200 \mathrm{~mm}$ ), after which the mass was measured on a precision scale $(0.1 \mathrm{~g})$.

The experimental design consisted of completely randomized blocks. Each of the four metering mechanisms characterized a block. The combination of levels of each factor (seven longitudinal inclinations and two preestablished doses) within each block (metering mechanism) determined the plot. Each plot was individualized by the exposure time (30 seconds) of the metering mechanism to the collection container. Three replications were performed, totaling 168 collections.

The statistical modeling was obtained by characterizing the response variable ( $\mathrm{z}$ - actual dose) as a function of predictor variables $(\mathrm{x}-$ inclination and $\mathrm{y}-$ preestablished dose measured at $0^{\circ}$ ), allowing the establishment of the response surface. The regression model characterization was obtained through [eq. (1)]:

$\mathrm{z}=\beta_{0}+\beta_{1} \mathrm{x}_{1}{ }^{2}+\beta_{2} \mathrm{y}_{1}{ }^{2}+\mathrm{x}_{1} \mathrm{y}_{1}+\beta_{3} \mathrm{x}_{1}+\beta_{4} \mathrm{y}_{2}+\cdots \beta_{\mathrm{k}} \mathrm{x}_{\mathrm{k}}+\varepsilon$

Where:

$\mathrm{z}$ is the response variable;

$\mathrm{x}_{1}, \mathrm{y}_{1} \ldots \mathrm{x}_{\mathrm{k}}, \mathrm{y}_{\mathrm{k}}$ are the predictors, and

$\beta_{0}, \beta_{1}, \ldots \beta_{\mathrm{k}}$ are parameters, and $\varepsilon$ is the error.

The statistical evaluation was carried out by subjecting the results to the analysis of variance using the Ftest at $95 \%$ significance. Subsequently, multiple regression was performed, with the model adjustment analyzed by the coefficient of determination $\left(\mathrm{R}^{2}\right)$ using the software Excel and Statistica Trial Version Application v. 13.3.

\section{MATERIAL AND METHODS}

The results in Table 1 show that all the tested metering mechanisms had a dose variation when different terrain conditions were simulated, i.e., acclivity (positive longitudinal inclinations) and in level or declivity (negative longitudinal inclinations), with significant interaction between the factors inclinations and metering mechanisms. A significant variation was also observed for the factors inclination and dose, as well as dose and metering mechanism. Thus, the slicing of the interactions was carried out through multiple regression, which enabled an analysis of the response surface in three-dimensional space. 
TABLE 1. Analysis of variance for the analyzed factors.

\begin{tabular}{lccccc}
\hline \multicolumn{1}{c}{$\mathrm{SF}$} & $\mathrm{DF}$ & $\mathrm{SS}$ & $\mathrm{MS}$ & $\mathrm{Fc}$ & $\operatorname{Pr}>\mathrm{Fc}$ \\
\hline Inclination & 6 & 20023.87 & 3337.31 & 376.67 & 0.00 \\
Dose & 1 & 6143.90 & 6143.90 & 693.44 & 0.00 \\
Metering mechanism & 3 & 37006.86 & 12335.62 & 1392.28 & 0.00 \\
Inclination*Dose & 6 & 179.24 & 29.87 & 3.37 & 0.00 \\
Inclination*Metering & 18 & 34716.17 & 1928.68 & 217.68 & 0.00 \\
Dose*Metering & 3 & 123.62 & 41.21 & 4.65 & 0.00 \\
\hline Error & 133 & 1151.80 & 8.86 & & \\
\hline CV (\%) & 5.86 & & & & \\
\hline Total corrected & 167 & 99345.46 & & & \\
\hline Overall mean & 50.82 &
\end{tabular}

A model was adjusted for each metering mechanism to predict the actual dose $\left(\mathrm{kg} \mathrm{ha}^{-1}\right)$ of microgranular fertilizer, according to the variation of the longitudinal inclination and pre-established dose on level ground. Equations (2), (3), (4), and (5) presented coefficients of determination equal to 0.94 , $0.97,0.98$, and 0.97 , corresponding to the metering mechanisms 1, 2, 3, and 4, respectively.

$$
\begin{aligned}
& z=1.41 x+0.94 y+0.96 \\
& z=0.32 x^{2}-0.34 x+0.66 y+16 \\
& z=1.67 x+0.89 y+5.57 \\
& z=0,39 x+0.73 y+11.34
\end{aligned}
$$

Where:

$\mathrm{z}$ is the actual dose $\left(\mathrm{kg} \mathrm{ha}^{-1}\right)$;

$\mathrm{x}$ is the longitudinal inclination $\left({ }^{\circ}\right)$, and

$\mathrm{y}$ is the pre-established dose $\left(\mathrm{kg} \mathrm{ha}^{-1}\right)$.

Equation (3), which predicts the behavior of the metering mechanism with two helicoids, presents the highest variation with the inclination, as the actual dose varies squared with the inclination. Moreover, the metering mechanism 4 presented the lowest dose variation in the longitudinal direction, as [eq. (5)] had the lowest $\mathrm{x}$ coefficient, meaning that the dose increases $0.39 \mathrm{~kg} \mathrm{ha}^{-1}$ for each degree when the inclination variable (y) is fixed.
The metering mechanism 4 was developed specifically for the dose of microgranular fertilizer, according to the manufacturer. It has a duct on the inside and a cylinder on the outside of the helicoid, filling the volume and avoiding empty spaces inside the metering mechanism. According to Garcia et al. (2012), the fuller the helicoid is, the higher its efficiency. The reduction of empty spaces inside the metering mechanism minimizes the effects of gravity, which influences the high variability in the dose applied per hectare when working on sloping terrains.

Equations (2) and (4), which represent the behavior of the helical metering mechanism by longitudinal (M1) and lateral overflow (M3), respectively, showed similar variations relative to the inclination. Similar behavior was observed by Ferreira et al. (2010), Franck et al. (2015), and Garcia et al. (2017), who reported that metering mechanisms with longitudinal or lateral overflows when subjected to positive (acclivity) and negative (declivity) longitudinal inclinations cause increases and decreases, respectively, in the application rate.

Equation (2), used to predict the metering mechanism M1, allowed generating the 3D graph presented in Figure 2, showing the behavior of the variable actual dose (z-axis) as a function of longitudinal inclination ( $\mathrm{x}$-axis) and pre-established dose on level ground ( $\mathrm{y}$-axis). The response surface is a plan that the higher the longitudinal inclination of the terrain is, the higher the variation of the actual dose. 


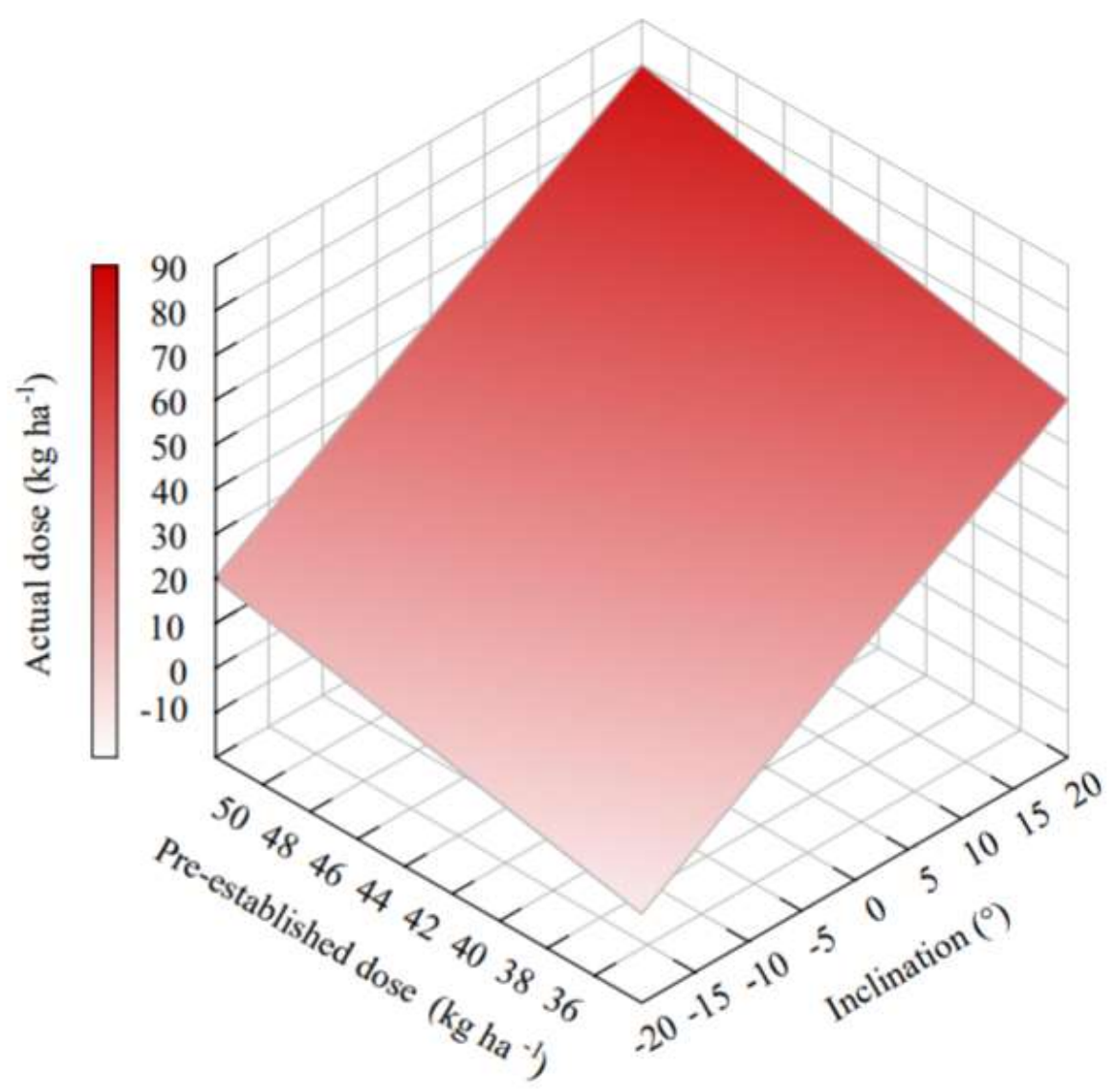

FIGURE 2. Behavior of the actual dose of microgranular fertilizer $\left(\mathrm{kg} \mathrm{ha}^{-1}\right)$ by the metering mechanism with longitudinal overflow (M1) as a function of the longitudinal inclination and pre-established dose.

The use of the metering mechanism with longitudinal overflow (M1), with the dose measured at the $0^{\circ}$ level for $35 \mathrm{~kg} \mathrm{ha}^{-1}$ using Equation (2) $\left(\mathrm{R}^{2}=0.94\right)$, allowed obtaining a value of $33.86 \mathrm{~kg} \mathrm{ha}^{-1}$, a reference value for determining the variation (\%) according to the tested inclination. Moreover, Equation (2) allowed obtaining a value of $12.71 \mathrm{~kg} \mathrm{ha}^{-1}$ for the $-15^{\circ}$ inclination, which characterizes a $-62.5 \%$ variation relative to the reference dose $\left(33.86 \mathrm{~kg} \mathrm{ha}^{-1}\right)$.

The inclinations $-10^{\circ}$ and $-5^{\circ}$ (declivity) showed a dose reduction in the order of $-41.6 \%$ and $-20.9 \%$, respectively, while the inclinations $+10^{\circ}$ and $+5^{\circ}$ (acclivity) had an opposite effect, i.e., the dose increased to $41.6 \%$ and $20.9 \%$, respectively. Similar behavior was observed when the dose was measured at the $0^{\circ}$ level for $50 \mathrm{~kg} \mathrm{ha}^{-1}$, with dose variations of $-44.1 \%,-29.4 \%,-14.7 \%,+14.7 \%$, $+29.4 \%$, and $+44.1 \%$ on the same longitudinal inclinations.

Garcia et al. (2017) researched a granular fertilizer and found dose variations of $-9.0 \%,-3.6 \%, 5.9 \%$, and $9.7 \%$ for inclinations of $-10^{\circ},-5^{\circ}, 5^{\circ}$, and $10^{\circ}$, respectively, while the powdered fertilizer reduced the variations to $-2.9 \%,-2.0 \%, 3.2 \%$, and $7.1 \%$, respectively. The variations found in the present study were higher than the variations found by Garcia et al. (2017) and, although the metering mechanism used was the same, the particle size and fertilizer dose were not the same. The authors used a dose measured at the $0^{\circ}$ level of $1.5 \mathrm{~kg} \mathrm{~min}^{-1}$, which is equivalent to $400 \mathrm{~kg} \mathrm{ha}^{-1}$, considering the use of a seedcum-fertilizer drill in level at a speed of $1.39 \mathrm{~m} \mathrm{~s}^{-1}$ and interrow spacing of $0.45 \mathrm{~m}$.
These dose variations are due to the different fertilizer characteristics. Particle size should favor the material flow through the metering element. However, fertilizers have large changes in the particle size, leading to different variations in the dose. A fertilizer registered in Brazil as a granular fertilizer must have at least 95\% of product passing through the $4.8 \mathrm{~mm}$ sieve, at most $40 \%$ passing through the $2 \mathrm{~mm}$ sieve, and at most $5 \%$ passing through the $1.0 \mathrm{~mm}$ sieve (Brasil, 2018).

The doses shown in Figure 2 varied according to the inclination. The higher the dose, the higher the dose variation, which corroborates with Rosa et al. (2019). However, the doses used are considered low, as the fertilizer Rizostar $\mathrm{PZ}^{\circledR}$ is used in soybean and corn, for example, at doses from 35 to 55 and 30 to $45 \mathrm{~kg} \mathrm{ha}^{-1}$, respectively. According to the manufacturer, its phosphorus protection technology prevents and blocks the action of soil cations, which can interfere and insolubilize phosphorus (P), increasing its availability to plants and reducing the fixation by soil minerals at the initial crop development stages.

The metering mechanism with two helicoids (M2), in which the fertilizer is moved to the nozzle after falling by gravity into the conducting tube, showed a paraboloid response surface (Figure 3 ) with a downward concavity. It indicates that the dose values increase from the center to the periphery, regardless of whether the inclination is positive or negative, resulting in doses higher than the reference $\left(0^{\circ}\right)$. It is due to the construction of the metering mechanism, as it has an arrangement of helicoids parallel to each other, rotating in the opposite direction, with mass flow exit on opposite sides (Spagnolo et al., 2018). 


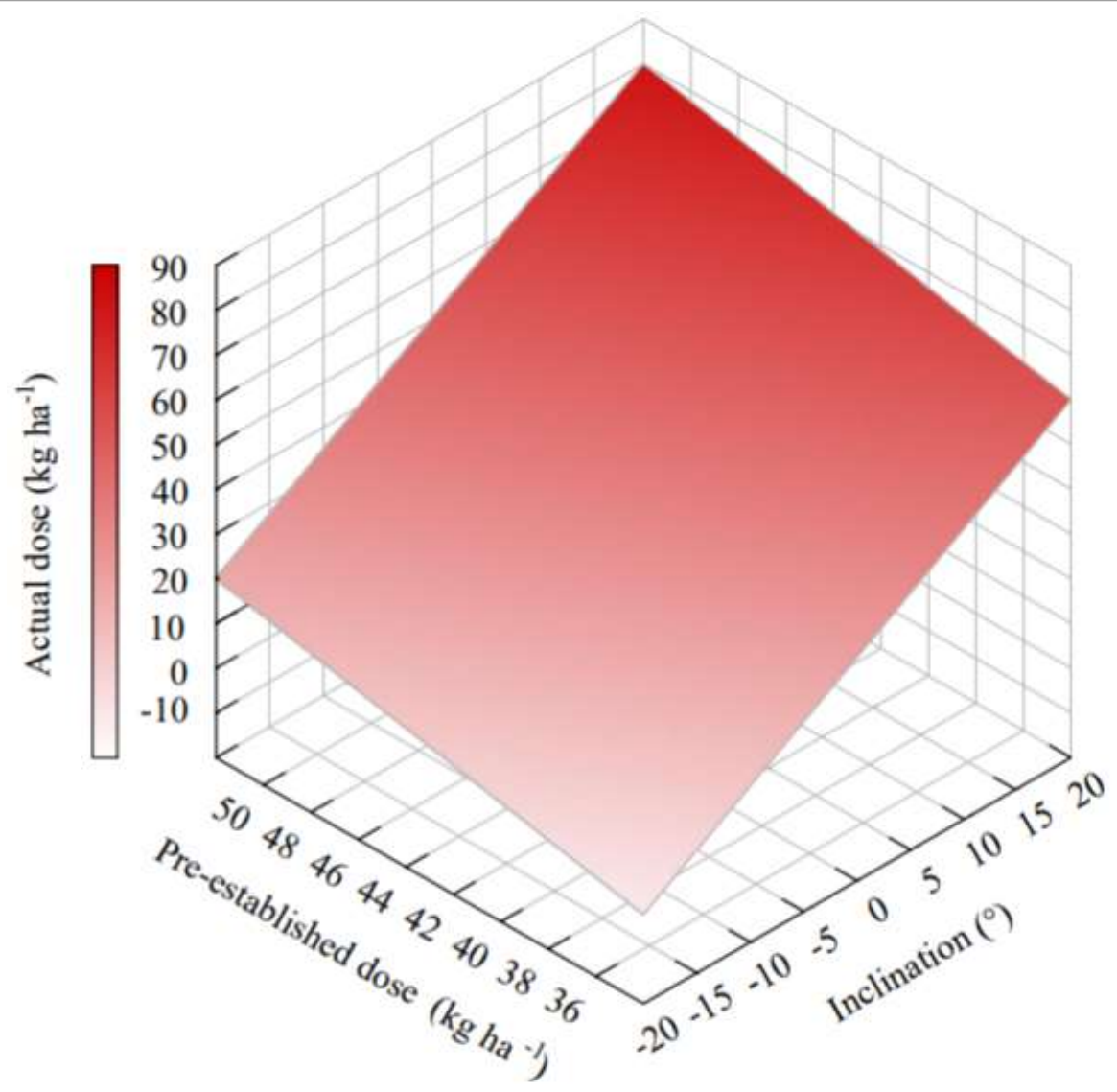

FIGURE 3. Behavior of the actual dose of microgranular fertilizer $\left(\mathrm{kg} \mathrm{ha}^{-1}\right)$ by the metering mechanism with two helicoids (M2) as a function of the longitudinal inclination and pre-established dose.

The use of the metering mechanism with two helicoids (M2) provided variations of $+197.2 \%,+91.8 \%$, $+68.8 \%,+60.7 \%,+73.1 \%$, and $+171.1 \%$ for inclinations of $-15^{\circ},-10^{\circ},-5^{\circ},+5^{\circ},+10^{\circ}$, and $+15^{\circ}$, respectively, when the dose was measured at the $0^{\circ}$ level for $35 \mathrm{~kg} \mathrm{ha}^{-1}$. The behavior was similar when the dose was measured at the $0^{\circ}$ level for $50 \mathrm{~kg} \mathrm{ha}^{-1}$, with variations of $+157.3 \%,+72.2 \%$, $+19.8 \%,+12.9 \%,+58.4 \%$, and $+136.5 \%$ for the mentioned longitudinal inclinations, respectively.

The highest variation when the lowest dose $(35 \mathrm{~kg}$ $\mathrm{ha}^{-1}$ ) was used occurs because the metering mechanism has a low fertilizer mass inside it and the speed is lower than at the highest dose $\left(50 \mathrm{~kg} \mathrm{ha}^{-1}\right)$. Therefore, gravity has a high acting power.

The behavior of the variation of the actual dose (Figure 4) in the metering mechanism with lateral overflow (M3) according to the inclination variation was similar to that of the metering mechanism D1 (Figure 2). The response surface is a plan in which the dose increases as the longitudinal inclination increases. 


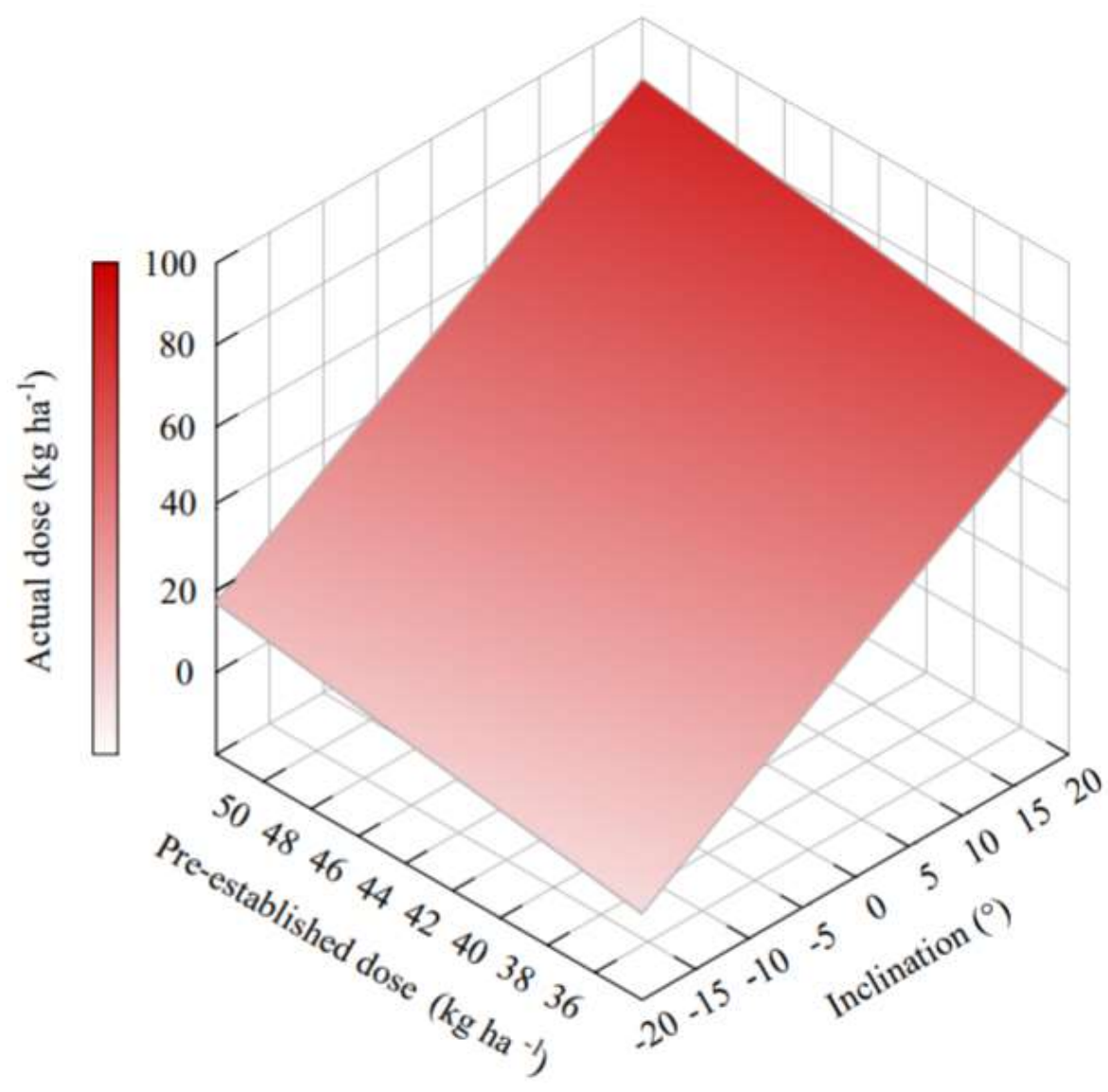

FIGURE 4. Behavior of the actual dose of microgranular fertilizer $\left(\mathrm{kg} \mathrm{ha}^{-1}\right)$ by the metering mechanism with lateral overflow (M3) as a function of the longitudinal inclination and pre-established dose.

The corrected dose when using the metering mechanism with lateral overflow (M3) measured at the $0^{\circ}$ level for $35 \mathrm{~kg} \mathrm{ha}^{-1}$ presented variations slightly above those observed in M1, with values of $-68.2 \%,-45.5 \%,-22.7 \%$, $+22.7 \%,+45.5 \%$, and $+68.2 \%$ for inclinations of $-15^{\circ}$, $-10^{\circ},-5^{\circ},+5^{\circ},+10^{\circ}$, and $+15^{\circ}$, respectively. A similar behavior was observed for a dose measured at the $0^{\circ}$ level for $50 \mathrm{~kg} \mathrm{ha}^{-1}$, with variations of $-50.0 \%,-33.4 \%,-16.7 \%$, $+16.7 \%$, $+33.4 \%$, and $+50.5 \%$ for the mentioned longitudinal inclinations, respectively. Garcia et al. (2017) used metering mechanisms with lateral overflow with granular fertilizer on the inclinations $-10^{\circ},-5^{\circ}, 5$, and $10^{\circ}$ and quantified low variations, with values of $-2.4 \%,-0.6 \%$, $3.2 \%$, and $4.7 \%$, respectively.

Dose variations in the metering mechanism M2 (Figure 3) were considerably higher than those presented by
M1 (Figure 2) and M3 (Figure 4). On the contrary, Spagnolo et al. (2018) used granular fertilizer and found that a metering mechanism with two helicoids submitted to the longitudinal inclination of the terrain presented lower dose variation than metering mechanisms with one helicoid, even though with an overflow mechanism. Therefore, the constructive characteristics of the metering mechanism M3 did not favor its use with low-dose microgranular fertilizers, as both acclivities and declivities presented overdoses, increasing production costs and the risks of environmental degradation (Serrano et al., 2014).

Figure 5 shows the behavior of a helical metering mechanism with longitudinal overflow for microgranular fertilizers (M4). The response surface is also a plan, which is similar to the metering mechanisms M1 (Figure 2) and M3 (Figure 4), but with low variations. 


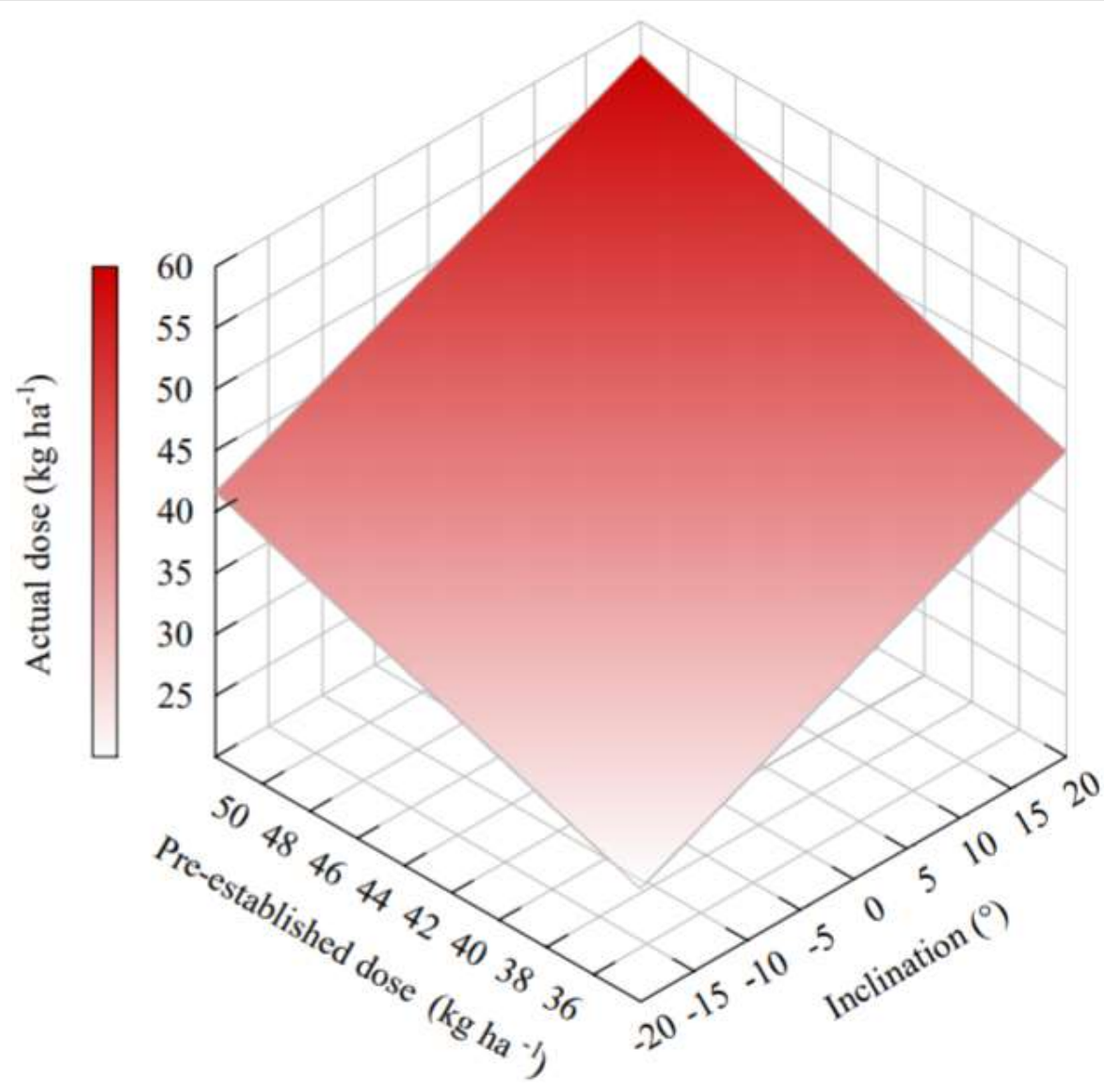

FIGURE 5. Behavior of the actual dose of microgranular fertilizer $\left(\mathrm{kg} \mathrm{ha}^{-1}\right)$ by the metering mechanism with longitudinal overflow specific for microgranular fertilizers (M4) as a function of the longitudinal inclination and pre-established dose.

The dose measured for $35 \mathrm{~kg} \mathrm{ha}^{-1}$ at the $0^{\circ}$ level led to the lowest dose variations, with values of $-15.9 \%$, $-10.6 \%, \quad-5.3 \%, \quad+5.3 \%,+10.6 \%$, and $+15.9 \%$ on inclinations of $-15^{\circ},-10^{\circ},-5^{\circ},+5^{\circ},+10^{\circ}$, and $+15^{\circ}$, respectively. Similar behavior was observed for the dose measured at the $0^{\circ}$ level for $50 \mathrm{~kg} \mathrm{ha}^{-1}$, with variations of $-12.3 \%,-8.2 \%,-4.1 \%,+4.1 \%,+8.2 \%$, and $+12.3 \%$ for the mentioned longitudinal inclinations, respectively. This metering mechanism presented the best performance compared to the others (M1, M2, and M3) when considering its constructive purpose, which has a reduction in internal spaces for metering low amounts of microgranular fertilizer.

Thus, the problem of the other metering mechanisms is related to the spaces (gaps) between the thread and the body of mechanisms, as well as the spaces in the center of the thread hollow helicoid, where fertilizer drips when seedcum-fertilizer drills are under operation on inclinations, corroborating with Reynaldo \& Gamero (2015). In addition, the better performance of the metering mechanism M4 occurred because it works with a fuller helicoid than to the others, corroborating with Garcia et al. (2012) and Galvão et al. (2018), who pointed out that constructive characteristics aiming at the reduction of empty spaces and hence the gravity action allow an increase in the efficiency of fertilizer-metering mechanisms. Each metering mechanism has speed ranges in which the helicoid assists more efficiently the fertilizer flow, providing better distribution (Camacho-Tamayo et al., 2009; Bonotto et al., 2013). In the present study, the metering mechanism M4 was the only one used within the speed range recommended by the manufacturer, evidencing that metering errors may occur due to the use of inappropriate or improperly regulated equipment, out of the manufacturer's recommendations.

There is, therefore, a gap in the market of fertilizermetering mechanisms due to the growing use of fertilizers with different low-dose formulations, which should receive higher attention from manufacturers and research institutions. An alternative would be modifications in the design, perhaps with the use of a tapered thread, as proposed by Galvão et al. (2018), or the use of smaller helicoid pitches.

Moreover, metering mechanisms that allow variation of the helicoid speed could be used to reduce dose errors, caused by helical fertilizer-metering mechanisms when the sowing operation is carried out with an inclination. For this, it is essential to use equations that predict the dose variation according to the terrain variation, so that the dose can be measured instantly during the operation of the seed-cumfertilizer drill.

\section{CONCLUSIONS}

Metering mechanisms with one helicoid (M1, M3, and M4) showed a dose variation as a function of the inclination, with a linear behavior. The higher the longitudinal inclination, the higher the dose.

Metering mechanisms with a helicoid and longitudinal (M1) and lateral overflow (M3) presented a similar dose according to the variation of the longitudinal inclination.

The metering mechanism with two helicoids (M2) showed the highest dose variation of microgranular fertilizer, with the dose varying squared with the longitudinal inclination. 
The metering mechanism with longitudinal overflow (M) for microgranular fertilizers had the lowest less variation when applying microgranular fertilizer at low application rates.

\section{REFERENCES}

ABNT - Associação Brasileira de Normas Técnicas (2003) NBR NM 248 Agregados - Determinação da composição granulométrica. ABNT, 6p.

Brasil (2018) Instrução normativa $n^{\circ} 39$, de 8 de agosto de 2018. Available:

http://www.agricultura.gov.br/assuntos/insumosagropecuarios/insumos-agricolas/fertilizantes/legislacao/in39-2018-fert-minerais-versao-publicada-dou-10-8-2018.pdf. Accessed: Dec 17, 2019.

Bonotto GJ, Alonço AS, Bedin PR, Altmann AS, Lauri JM (2013) Distribuição longitudinal de fertilizantes por dosadores de semeadoras adubadoras em linhas. Engenharia na Agricultura 21:368-378. DOI: https://doi.org/10.13083/reveng.v21i4.405

Camacho-Tamayo JH, Barbosa AM, Pérez NM, Leiva FR, Rodríguez GA (2009) Operational characteristics of four metering systems for agricultural fertilizers and amendments. Engenharia Agrícola 29:605-613. DOI: http://dx.doi.org/10.1590/S0100-69162009000400010

Ferreira MFP, Dias VO, Oliveira A, Alonço AS, Baumhardt UB (2010) Uniformidade de vazão de fertilizantes por dosadores helicoidais em função do nivelamento longitudinal. Engenharia na Agricultura 18:297-304. DOI: https://doi.org/10.13083/reveng.v18i4.234

Francetto TR, Dagios RF, Leindecker JÁ, Alonço AS, Ferreira MF (2015) Características dimensionais e ponderais das semeadoras-adubadoras de precisão no Brasil. Tecno-Lógica 19:18-24. DOI: http://dx.doi.org/10.17058/tecnolog.v19i1.4500

Franck CJ, Alonço AS, Machado ODC, Francetto TR, Carpes DP, Bellé MP (2015) Mathematical models for selection of helical fertilizer metering mechanism with different fertilizer discharge. Revista Brasileira de Engenharia Agrícola e Ambiental 19:512-518. DOI: http://dx.doi.org/10.1590/1807-1929/agriambi.v19n5p512-518
Galvão CB, Albiero D, Garcia AP, Monteiro LA (2018)

Fertilizer metering mechanism with helical conic cylindrical thread for family agriculture. Engenharia Agrícola 38:934940. DOI: http://dx.doi.org/10.1590/1809-4430eng.agric.v38n6p934-940/2018

Garcia AP, Cappelli NL, Umezu CK (2012) Auger-type granular fertylizer distributor: mathematical model and dynamic simulation. Engenharia Agrícola, Jaboticabal 32:151-163. DOI: http://dx.doi.org/10.1590/S010069162012000100016

Garcia LC, Diniz RN, Rocha CH, Souza NM, Weirich Neto PH (2017) Desempenho de mecanismos de medição de adubos de plantadores como uma função de inclinação longitudinal. Engenharia Agrícola 37:1155-1162. DOI: http://dx.doi.org/10.1590/1809-4430eng.agric.v37n6p1155-1162/2017

ISO - International Organization for Standardization (1984) ISO 5690/2 Equipment for distributing fertilizers Test methods - Part 2: Fertilizer distributors in lines. ISO, $13 p$.

Reynaldo ÉF, Gamero CA (2015) Avaliação de mecanismos dosadores de fertilizantes helicoidais em ângulos de nivelamento longitudinal e transversal. Energia na Agricultura 30:125-136. DOI:

https://doi.org/10.17224/EnergAgric.2015v30n2p125-13

Rosa DP, Pagnussat L, Alves A, Pesini F, Spagnolo RT (2019) Methodology to evaluate the fertilizer distribution by helical doser from seed planter. Journal of Experimental Agriculture International 31(5):1-7. DOI: https://doi.org/10.9734/jeai/2019/v31i530087

Serrano J, Peça J, Silva JM, Shahidian S (2014) Fertilizers application: technology, energy efficiency and environment. Revista de Ciências Agrárias 37:270-279.

Spagnolo RT, Pinho MS, Oldoni A, Rosa DP (2018) Mais é melhor. Cultivar Máquinas 181:13-14. 